\title{
MORPHOLOGICAL AND ANATOMICAL STUDIES OF Acacia saligna (Labill.) Wendl. THE DOMINANT PLANT SPECIES IN AL-AHRASH PROTECTORATE-RAFAH-NORTH SINAI- EGYPT
}

(Received: 25.8.2008)

\author{
By \\ K. F. El-Sahhar, D. M. Nassar, W. M. Amer* and L. A. Qasem \\ Department of Agricultural Botany, Faculty of Agriculture, \& *Department of Botany, \\ Faculty of Science, Cairo University, Giza, Egypt.
}

\begin{abstract}
The purpose of this study is to find out the effect of environmental conditions prevailing at Al-Ahrash protectorate, Rafah, north Sinai, Egypt; being close to the Mediterranean shore and falls under its climatic influence on various botanical attributes of Acacia saligna the dominant plant species in this area.

This study indicates that this plant proved high efficiency as an adaptable species that is best developed under local prevailing conditions of such area. This encourages its incorporation into future developing resources projects. Morphological information was considered including plant habit and various vegetative and reproductive organs of plant. In addition, anatomical structure was investigated; including the root, the root nodule, the branchlet, the branch, the leaflet and the phyllodes at various developmental stages.
\end{abstract}

Key words: Acacia saligna, Al-Ahrash protectorate, anatomy, morphology, phyllode development.

\section{INTRODUCTION}

A national strategy and action plan for biodiversity conservation was prepared to meet Egypt's commitments under the Convention on Biological Diversity (CBD). The plan covers the period from 1997 to 2017 and sets goals for the protection of ecosystems and their sustainable management. The Government of Egypt has passed a number of laws concerned with nature conservation and environmental affairs among which Law 102/1983, the cornerstone of modern conservation efforts in Egypt. It established the legal framework that enabled the Government to create and manage protected areas in the country (Mikhail, 2002).

Nowadays, 27 protectorates were declared in the framework of Law 102/1983; in addition, 15 protectorates are proposed for declaration by 2017 which cover about 20\% of Egypt's territories (Anon., 1998 and 2008).

Al-Ahrash protectorate $\left(31^{\circ} 18 \mathrm{~N} 34^{\circ} 14 \mathrm{E}\right)$ an area of $8 \mathrm{~km}^{2}, 370 \mathrm{~km}$ eastern Cairo; in Rafah, north Sinai, was declared as a developing resources protected area according to the Prime Ministerial Decrees 1429/1985 and 3379/1996. This area is distinguished by sand dunes measuring some $60 \mathrm{~m}$ above sea level. The vegetation of this area, Acacia saligna is the dominant plant species, is mainly serving for sand dune fixation to stop sand movement (Anon, 2001).

Acacia is a pantropical genus comprises more than 1450 species. At present the following three subgenera are recognized within Acacia sens. lat. : Acacia, Aculeiferum and Phyllodineae. Pantropical subgenus Acacia and Aculeiferum include 161 and 207 species; respectively, and the subgenus Phyllodineae with about 1045 species is mainly confined to Australia (Lewis, 2005). Acacia saligna belongs to subgenus Phyllodineae and section Phyllodineae. It grows in a variety of habitats but prefers deep sandy soils in wet areas. The characters of Acacia saligna that led to its high rating as a potential crop species included ease of establishment, fast growth rates and the ability to produce large quantities of biomass that can be used for fuel wood, charcoal production, particle boards and livestock feed (Maslin and McDonald, 2004).

In addition to several authors, World Wide Wattle and many other web links to Acacia saligna dealt with its various botanical aspects. Moreover, many detailed investigations are available on different species of Acacia; e.g., Fahn 
et al., 1968; Metcalfe and Chalk, 1979; Hanna, 1984; Iqubal and Ghousi, 1987; Gourlay, 1995; Blakesley et al., 2002 and Gómez-Acevedo et al., 2007).

Fahn (1959) stated that no growth rings were found in Acacia saligna and the cambium is active throughout the year, reaching a peak during February-May. The vessels are prevailingly arranged in multiples of 2-4 (9), irregular clusters and solitary vessels are also common. The pits are vestured.

Fox (1995) reviewed published information pertaining to Acacia saligna endemic to southwestern Australia. $\mathrm{He}$ mentioned that its comparatively rapid early growth and tolerance of sandy, coastal soils provided stimulus for its use in fixing of sand dunes in many countries. Consequently it has also been cultivated for fodder in countries with a Mediterranean climate and is an important weedy species in South Africa. Growth and regeneration studies are reported.

So (2004) mentioned that pit-shaped extrafloral nectaries are not obvious externally and can only be found by careful examination. An even more obscure pit is seen in species of Acacia at leaf base, on side of pulvinus or along petiole.

Evert (2006) stated that Acacia saligna growing in the Mediterranean region exhibited cambial activity throughout most or all of the year, as do their Southern Hemisphere counterparts. Adaptation is believed to consist in developing long roots capable of tapping underground water.

Referring to the International Convention on Biological Diversity (CBD), 1994 to which Egypt is a signatory and the national plan mentioned in the National Biodiversity Report (1997); it is requested to enhance biological researches in natural reserves. Consequently, this study was carried out to elucidate the morphological and anatomical attributes of Acacia saligna the dominant multipurpose species in Al-Ahrash protectorate to find out the effect of prevailing climatic conditions on behaviour of this plant under the environmental influence of the Mediterranean region. This study provides the pioneer detailed morphological and anatomical information about Acacia saligna under the Egyptian conditions. Obviously, any new information in this concern is welcomed.

\section{MATERIALS AND METHODS}

\subsection{Sampling procedure}

The present study deals with various botanical aspects of Acacia saligna (Labill.) Wendl. collected from Al-Ahrash protectorate, Rafah, north Sinai, Egypt. In a previous paper (El-Sahhar et al., 2009) features of this area were given in detail. The vegetation analysis carried out proved that Acacia saligna is the dominant plant species in Al-Ahrash protectorate. It is then interesting to carry out a detailed study of morphological and anatomical attributes of this plant developing close to the Mediterranean shore and falls under its climatic influence.

Ten quadrates each measured $20 \times 20=400$ $\mathrm{m}^{2}$ were selected representing the whole studied area. Studied samples were collected randomly from these quadrates through March 2008. Observations were recorded on-site and prevailing conditions of the studied area were photographed. Samples representing different organs of Acacia saligna were collected for further morphological and anatomical studies.

\subsection{Measurement of phyllode area}

The range and average area of Acacia saligna phyllodes (leaf-like petioles and no blade) were carried out on samples resembling various sizes developed on mature branches. It was possible to classify collected samples into five groups according to their size. Each group comprised 20 phyllodes. Area of each of $5 \times 20$ collected phyllodes was measured using Leaf Area Meter (Model LI-3000, USA).

\subsection{Anatomical studies}

Microscopical study was carried out on the vegetative organs of Acacia saligna. Specimens included lateral root, root nodule, branchlet and branch at the middle portion showing the primary and secondary state of growth, old branch, leaflet and young and mature phyllodes at the middle portion.

Microtechnique procedures given by Nassar and El-Sahhar (1998) were followed. Specimens were killed and fixed for at least $48 \mathrm{hrs}$ in FAA (10 $\mathrm{ml}$ formalin, $5 \mathrm{ml}$ glacial acetic acid, $25 \mathrm{ml}$ distilled water, $60 \mathrm{ml}$ ethyl alcohol 95\%). After fixation, materials were washed in 50\% ethyl alcohol and dehydrated in a normal butyl alcohol series before being embedded in paraffin wax ( $\mathrm{mp}$ $56-58^{\circ} \mathrm{C}$ ). Transverse sections $20 \mu \mathrm{m}$ in thickness were cut on a SLEE Technik G mbH, Type cut 4050 rotary microtome (Mainz, Germany), stained with safranin / light green before mounting in Canada balsam and covering. Slides were analysed microscopically and photomicrographed. 


\section{RESULTS AND DISCUSSION}

Al-Ahrash protectorate is a nearly pure community of Acacia saligna trees. (El-Sahhar et al., 2009). A great deal of research on this plant has been conducted in Australia (country of origin) and in South Africa. It seems likely to carry out a study on various botanical aspects of this plant subjected to local environmental conditions prevailing in such area, which falls under the climatic influence of the Mediterranean shore.

\subsection{Morphological information \\ 3.1.1. Habit}

Acacia saligna proved its efficiency as an adaptable multipurpose species that is best developed under environmental conditions prevailing at Al-Ahrash protectorate (Fig. 1). This encourages its incorporation into future developing resources projects.

Acacia saligna is an evergreen, small dense, many-stemmed bushy shrub, $2-5 \mathrm{~m}$ in height. It reaches $3.75 \mathrm{~m}$ in the study area (El-Sahhar et al., 2009) (Fig. 2). The tree branches normally slightly flexuous; but there is a form which is a tree, with a distinct trunk up to $30 \mathrm{~cm}$ in diameter, with the crown 2-6 m wide (Fig. 3). Plants show fast growth rate. Trees exhibit high coppicing ability, since they show regrowth if main stem cut at ground level and resprout from the base following any harmful effect (Fig. 4). Plants also have a vigorous suckering propensity; i.e., they form thickets due to root suckering which is of interest in dune control (Fig. 5). The bark is smooth and grey to reddish-brown at the level of the twig, on old trees the bark is dark grey, slightly roughened and fissured (Fig. 12).

\subsubsection{Phyllode}

Fig. (6) shows the successive stages of foliage modification of Acacia saligna from true leaves at seedling stage to phyllodes through the whole plant life. The juvenile leaves at early seedling stage are compound, bipinnate with 8 pairs of paripinnate leaflets and tend to lie flat on the soil surface. Soon, the leaflets are suppressed and the leaf-stalk (petiole) starts to develop modified flat leaf-like structures, vertically flattened, taking on the function of a leaf blade before all leaflets are shed. These leaf-like petioles (and no blade) are known as phyllodes.

Phyllodes of Acacia saligna in area of study are variable in size. Representative phyllode samples were collected. It was possible to sort phyllodes into five groups according to their size (Fig. 7 and Table 1). Phyllodes varied from narrow lanceolate $6.8 \times 1.5 \mathrm{~cm}$ (group 1) to broad elliptical, reaching a maximum of $17.0 \mathrm{~cm}$ long and $6.5 \mathrm{~cm}$ wide (group 5). The average area of phyllodes varied from $24.2 \mathrm{~cm}^{2}$ in the smallest group to $87.6 \mathrm{~cm}^{2}$ in the largest one. However, the phyllode area, in general, ranged from 21.9 to 91.3 $\mathrm{cm}^{2}$ with an average of $55.5 \mathrm{~cm}^{2}$.

Fox (1995) mentioned that environmental factors appear to influence phyllode size. Some trees have predominantly large phyllodes and others predominantly narrow. Broad phyllode form appears to be particularly common in plants growing on limestone soils near the sea. Seedlings watered to excess produce narrower phyllodes, both forms occur side-by-side.

Phyllodes are dark green to blue green in colour, glabrous and normally largest at base of branches. Phyllode arrangement is alternate, one phyllode per node. It has a prominent longitudinal 1-nerved on each face and finely penninerved, entire, margin smooth, with symmetrical base and blunt tip, stipule absent. Phyllode is non succulent with pulvinus base, 1-2 mm long, coarsely wrinkled and well developed.

Extrafloral disk-like gland 1-2 mm wide is prominent, situated on upper margin of the phyllode, close to the pulvinus base.

Table (1): Various parameters of phyllodes developed on mature Acacia saligna branches at Al-

Ahrash protectorate.

\begin{tabular}{|c|c|c|c|}
\hline Groups & $\begin{array}{c}\text { Phyllode } \\
\text { length } \mathbf{x} \\
\text { width } \\
(\mathbf{c m})\end{array}$ & $\begin{array}{c}\text { Average } \\
\text { phyllode } \\
\text { area } \\
\left.\mathbf{( c m}^{\mathbf{2}}\right)\end{array}$ & $\begin{array}{c}\text { Range of } \\
\text { phyllode area } \\
\left.\mathbf{( c m}^{2}\right)\end{array}$ \\
\hline 1 & $6.8 \times 1.5$ & 24.2 & $21.9-27.5$ \\
\hline 2 & $10.5 \times 2.0$ & 42.4 & $40.5-46.3$ \\
\hline 3 & $12.5 \times 3.5$ & 47.3 & $40.8-50.8$ \\
\hline 4 & $14.5 \times 5.0$ & 75.8 & $71.2-79.5$ \\
\hline 5 & $17.0 \times 6.5$ & 87.6 & $80.5-91.3$ \\
\hline Overall & - & 55.5 & $21.9-91.3$ \\
\hline
\end{tabular}

\subsubsection{Inflorescence}

Inflorescences of Acacia saligna comprised 212 headed racemes, arranged in the axil of phyllodes. The inflorescence is enclosed when young by imbricate bracts, with bract scars evident at anthesis. Raceme axes measured 3-30 $\mathrm{mm}$ long, glabrous. Peduncles are $5-15 \mathrm{~mm}$ long, glabrous. Acacia saligna is characterized by globular heads orange-yellow in colour, mostly 7 $10 \mathrm{~mm}$ in diameter with 25-55 flowers.

\subsubsection{Flower}

Acacia saligna flowers from March to June. Flowers are hermaphrodite; stalkless, 3-4 mm long, mostly hairless, composed of short calyx 


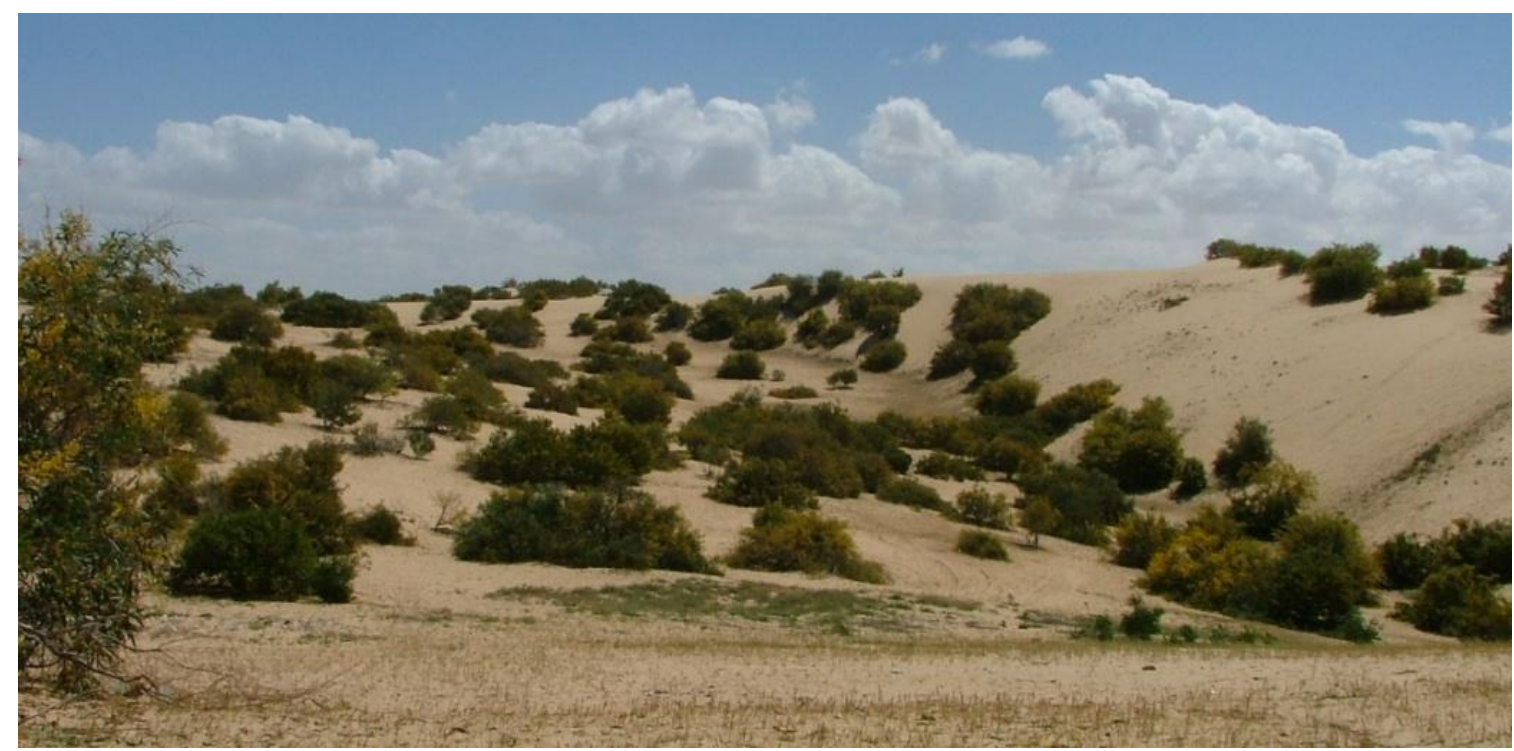

Fig. (1): Acacia saligna proved its efficiency to develop under Al-Ahrash protectorate conditions.



Fig. (2): Acacia saligna at Al-Ahrash protectorate forming many- stemmed bushy shrub 




Fig. (3): Acacia saligna at Al-Ahrash protectorate forming a tree with a distinct trunk (single-stemmed).



Fig. (4): Acacia saligna old tree at Al-Ahrash protectorate showing coppice regrowth following cutting of the main stem. 



Fig. (5): (A). Thicket of Acacia saligna growing in quadrate 7 at Al-Ahrash protectorate spreads by means of suckers. (B). Magnified portion of (A) showing the sucker. 


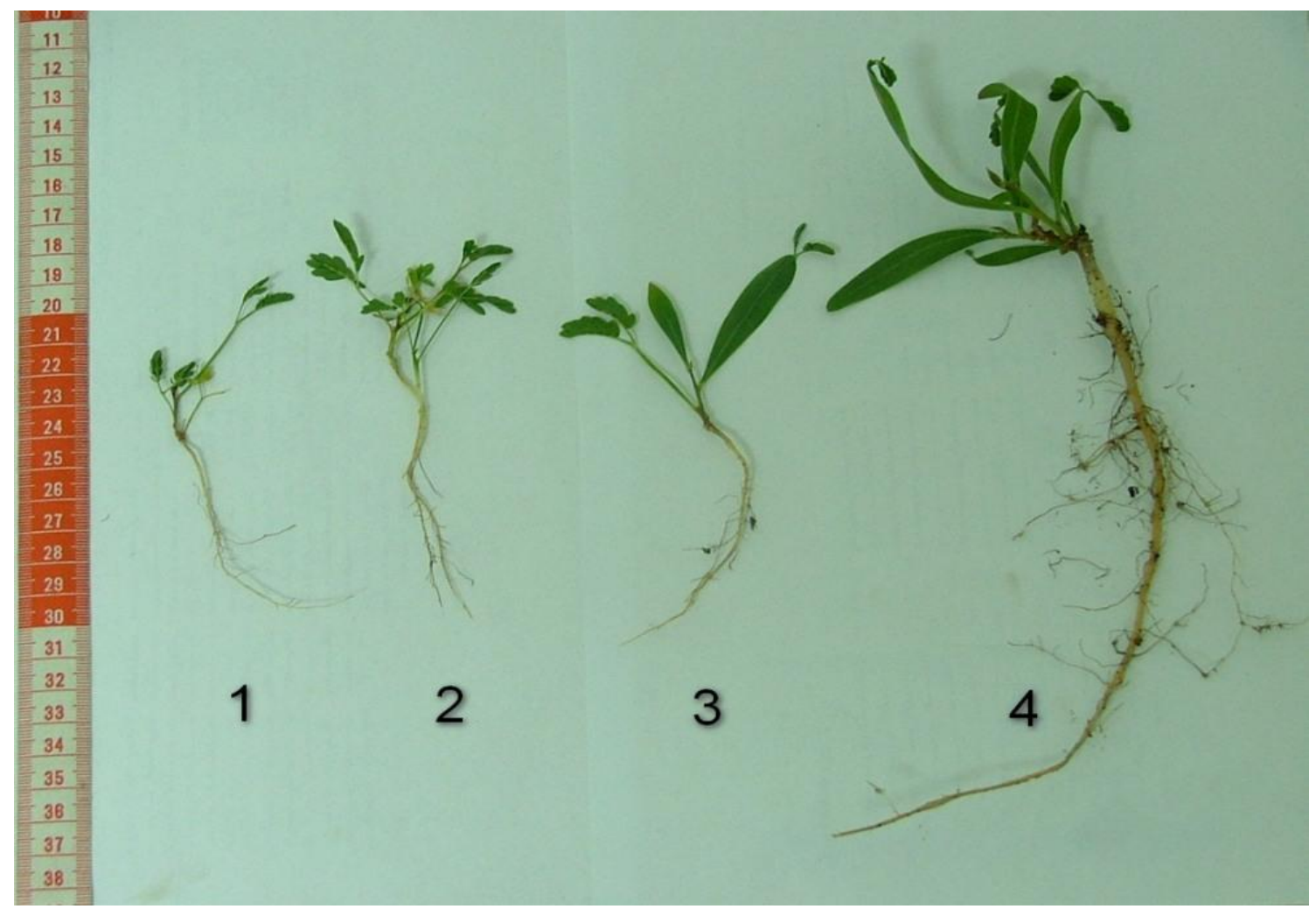

Fig. (6): Stages of foliage modification of Acacia saligna from true leaves to phyllodes.

1 and 2. Early seedling stages developing true leaves (compound paripinnate leaf). 3. The petiole starts to develop modified flat leaf-like structures (phyllodes) and leaflets fall off. 4 . All the true leaves develop to phyllodes.

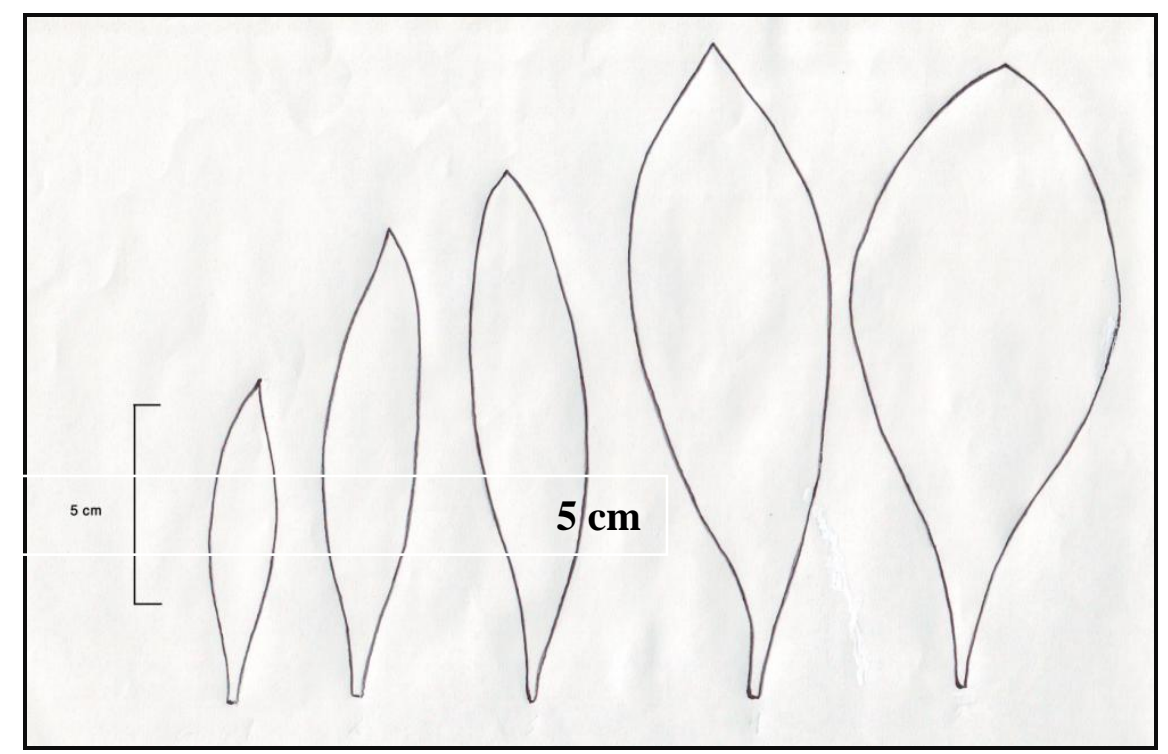

Fig. (7): Diagramme showing diversity of phyllode size of Acacia saligna at Al-Ahrash protectorate. 
with conical tube of 5 lobes. Corolla 5 narrow, long-pointed petals united near base. Stamens numerous thread-like. Pistil with ovary and slender style, with marginal ovules.

\subsubsection{Pod}

Pods of Acacia saligna are straight to strongly curved, linear, flat, shallowly constricted between seeds, 8-14 cm long, 4-6 $\mathrm{mm}$ wide, thinly coriaceous and glabrous.

\subsubsection{Seed}

Seeds of Acacia saligna are longitudinal, oblong to slightly elliptic, 4-6 mm long, 2-3 mm wide, shiny, dark brown to black and funicle short, clavate, expanded towards seed and white in colour.

The retrieved morphological characters of Acacia saligna under the studied area conditions are in harmony with those given by various researchers and mentioned in several web links, among them:

Acacia Search, Aluka, Answers.com, Australiannbg, Connecticut Univ., Factnet, Gmail, Plants for a future, Plantnet, Purdue Univ., USDA plants, Worldagroforestry and World Wide Wattle.

In addition to the following references:

Anon. (1980), Danin (1983 and 1986), Krebs et al., (2003), Kutiel et al. (2004), Maslin and McDonald (2004), So (2004) and Lewis (2005).

\subsection{Anatomical information}

\subsubsection{Structure of the root}

The transverse section through the tap root of Acacia saligna (Fig. 8) reveals its secondary state of growth. The root mainly comprises a vascular cylinder surrounded by a periderm. The amount of secondary elements increases and the xylem being more in amount than the phloem. The secondary growth is of the ordinary kind. The phellogen arises in the outer part of the pericycle and forms cork towards the outside. The secondary xylem contains vessels of various diameters. The vessels are accompanied by parenchyma cells. Wide rays of parenchymatous cells divide the outer layer of the axial xylem into sectors in radial rows. It is obvious that tanniniferous cells are situated in the phelloderm, phloem and medullary rays.

\subsubsection{Structure of the root nodule}

The nodule differentiated from the pericycle zone of the root (Fig. 9). The fully developed nodule consists of a mass of central cells containing bacteria and surrounded by a zone of parenchyma.

As far as the authors are aware no detailed studies dealing with anatomical structure of Acacia saligna root were previously carried out.

\subsubsection{Structure of the branchlet}

The anatomical structure of the branchlet of Acacia saligna was investigated in the form of transverse sections taken from its middle portion (Fig. 10). It is evident that the branchlet outline is triangular (winged and grooved). The epidermis is composed of a single layer, the epidermal cells are relatively small in size and covered with a thin cuticle layer. The epidermis is still intact and the periderm is not formed yet.

The cortex consists of 6-7 layers of parenchyma contains tannins underlying the epidermis followed by normal thin-walled compact parenchyma cells. The vascular cylinder composed of a large number of collateral bundles forming a continuous cylinder. The adjacent bundles are almost difficult to distinct from one another. The vascular bundles are still in the primary state of growth.

The pith consists of relatively large polygonal parenchyma cells, which tend to decrease in size towards the periphery. The peripheral region of the pith contains tannins. It is worthy to note that tanniniferous cells are also observed in the phloem and xylem.

\subsubsection{Structure of the branch}

The transverse section through the mature branch is shown in Fig. (11). The branch is almost cylindrical in its outline. The epidermis is ruptured and the periderm is formed. Cork contains densely tannineferous cells. The fibre groups abutting the secondary phloem is well defined. The secondary thickening proceeds and the secondary growth is present in a continuous cylindrical form. The vascular cambium is still producing more secondary xylem than secondary phloem (the amount of xylem represents about $60 \%$ of the whole section). The vessels typically solitary with a few multiples of 2 or 3 cells and are radially and sometimes even tangentially oriented. Xylem rays are homogeneous. Ray cells contain tannins. Fibres are moderately thickwalled. The pith still intact and consists of lignified cells and its outer part filled with tannins.

The present findings of the branch structure of Acacia saligna are generally in accordance with those found by Fahn (1959) and Metcalfe and Chalk (1979).

Old branches toward the basal part of Acacia saligna tree are characterized by dark grey and cracked bark (Fig. 12 A). Wood of sectioned branch (Fig. $12 \mathrm{~B} \& \mathrm{C}$ ) is pale-coloured and no annual growth rings can be distinguished.

This is in conformity with that given by Fahn (1959). He also mentioned that the cambium is 

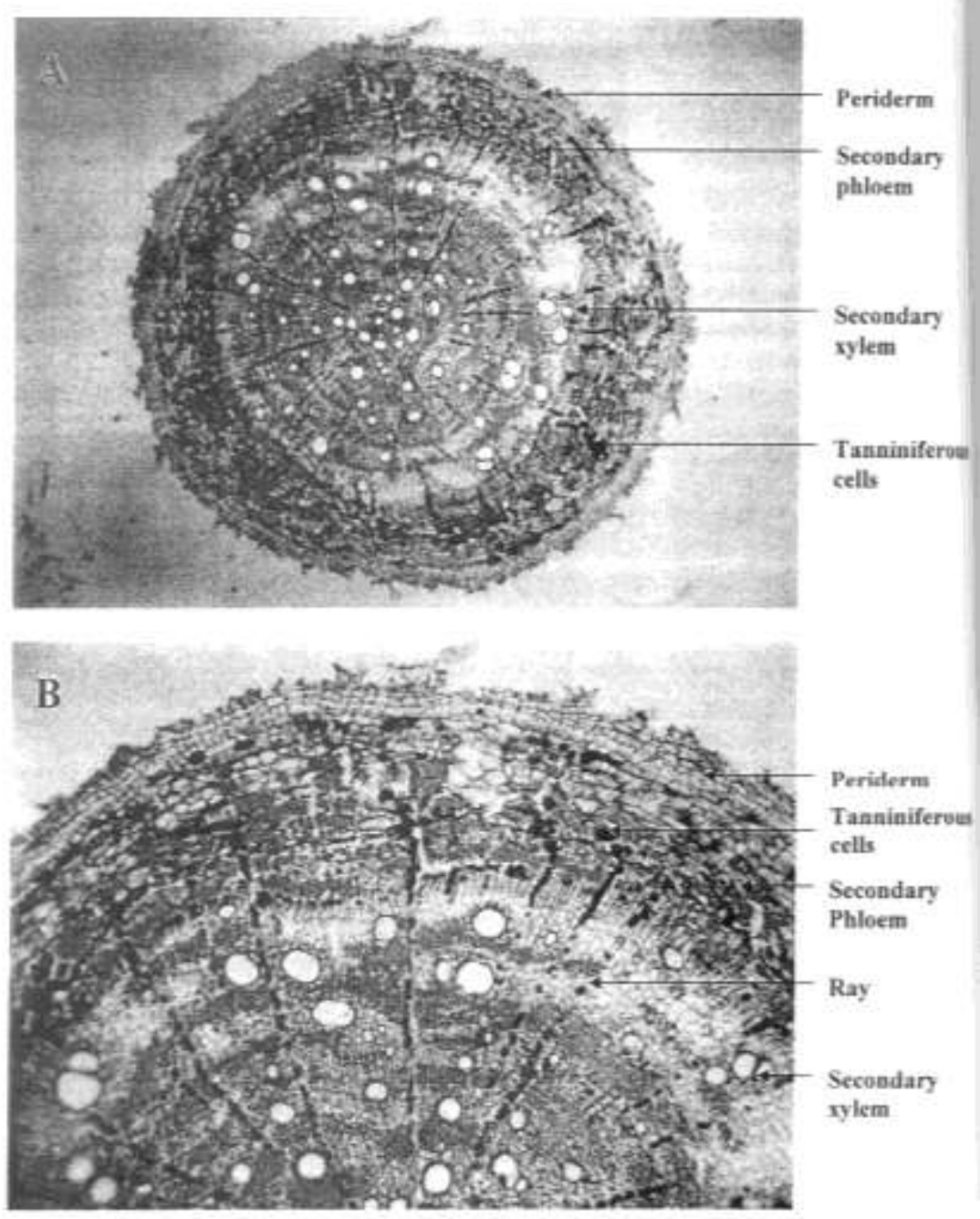

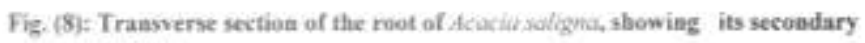
struchure.

A: Whole section. (X 52)

B: Magnified portioe of A. ( $\mathrm{X}$ 144) 

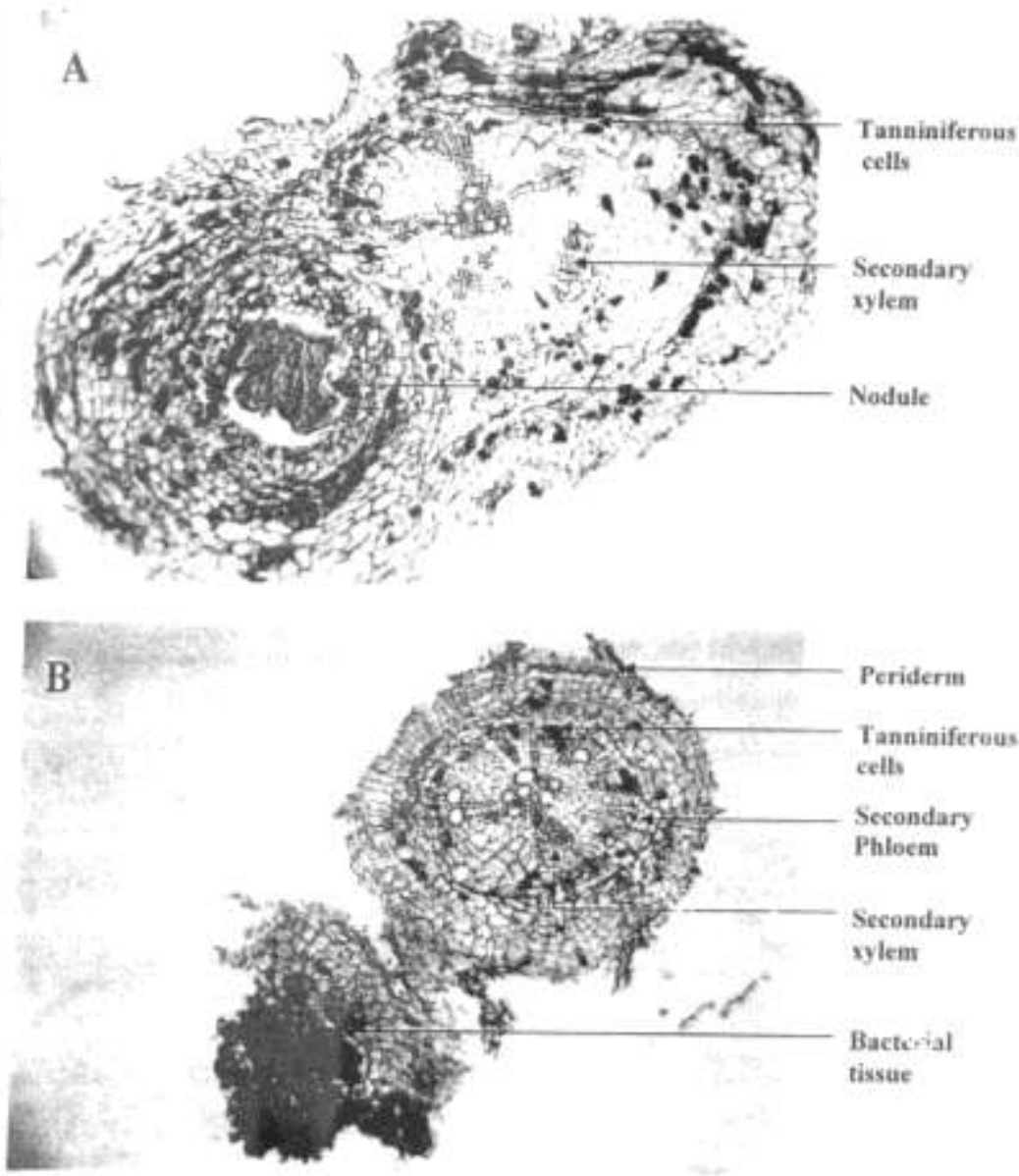

Fie. (9): (AAB). Transverse sectiuns through the secondary root of Acucial xaligna, showing the differcatiatioa of reot nodule. (X52) 




of Errowth.

A. Alausat whale sestiua. (X 52 )

B. Magnified groove and C, augaified miag sbowe in Fie. A. (X 144) 

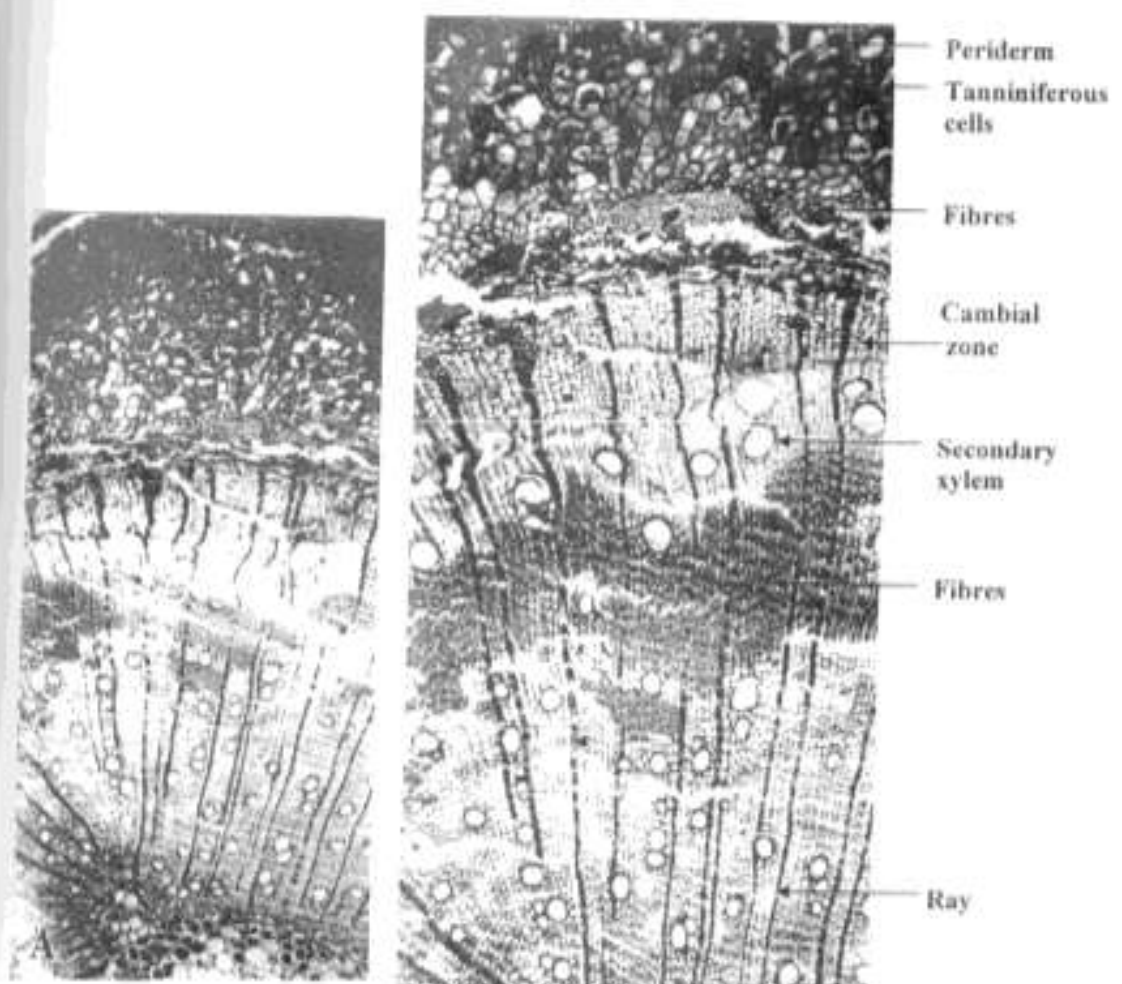
cells
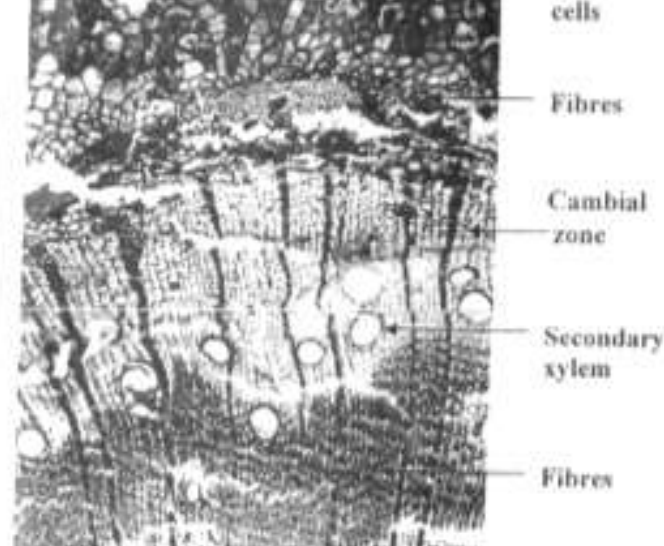

Nibres
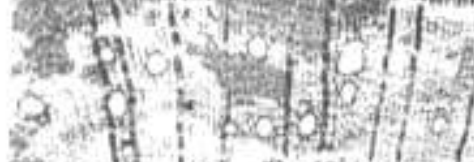

fenthey
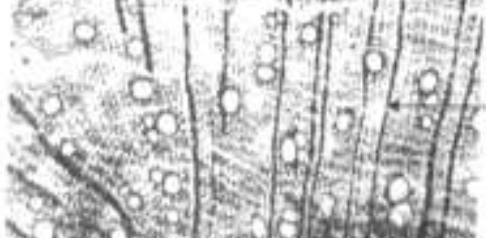

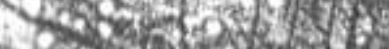

now
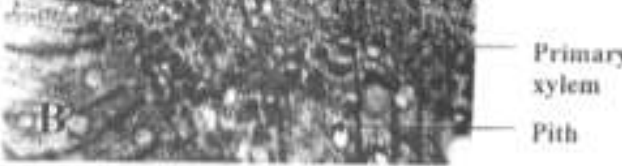

Fig. (11): Transwerse scction of Acacia sadigna hanch, showing secosdary state of growth.

A. Sestor. (X 52 )

B. Magaified portion of $\mathrm{A}$. ( $\mathrm{X}$ (44) 

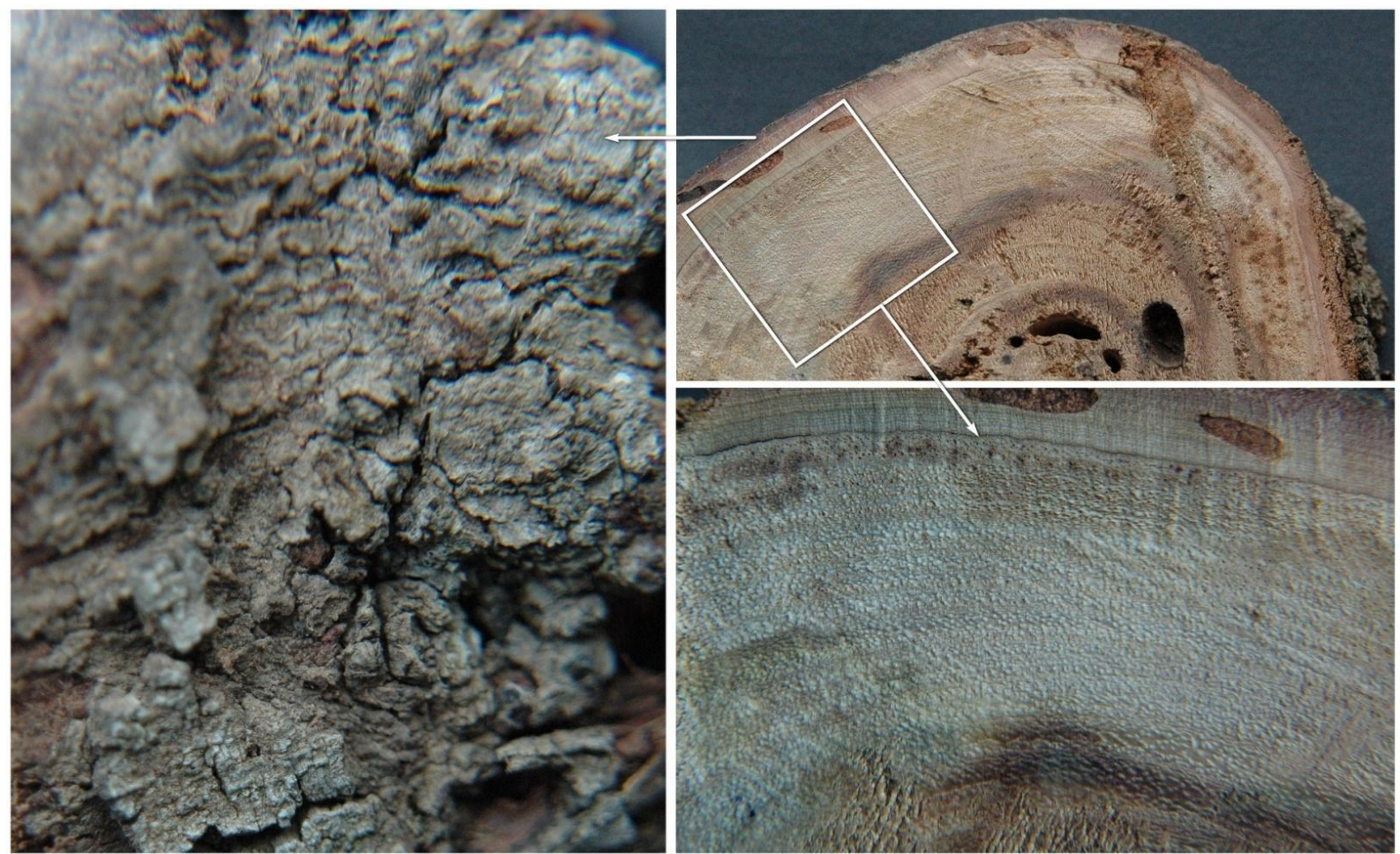

Fig. 12. Basic part of a branch of Acacia saligna old tree at Al-Ahrash protectorate. A; surface view of the bark ( dark grey and fissured); B and C; branch section showing pale-coloured wood, growth rings absent.

active throughout the year, reaching a peak during February - May.

\subsubsection{Structure of the leaflets}

As mentioned earlier through the morphological investigation, Acacia saligna leaf is compound bipinnate at early seedling stage, at the beginning of its differentiation. Transverse sections of the leaflet blades were examined (Fig. 13). It was found that leaflets are dorsiventral; i.e. the palisade tissue is located on the adaxial side of the blade and the spongy tissue on the abaxial one.

Compact arrangement of papillose epidermal cells and presence of cuticle layers and stomata are the main features of leaflet epidermis of Acacia saligna. The palisade tissue consists of one layer, sometimes two layers of cells being characterized by an abundance of chloroplasts. The palisade tissue occupies one-third of the whole thickness of the mesophyll. The spongy tissue is composed of five layers of chlorenchymatous loosely arranged cells with many intercellular spaces.

At the midrib region, two or three layers of collenchyma tissue are present beneath the lower epidermis underlying the phloem of the main vascular bundle. The vascular bundle of the midvein is relatively small in size and oriented with the xylem directed towards the adaxial surface and the phloem towards the abaxial one.

\subsubsection{Structure of the young phyllode}

As inferred earlier through the morphological investigation, leaflets of Acacia saligna fall off and the leaf-stalk starts to develop modified flat leaf-like structures known as phyllodes.

Transverse section through the young phyllode is shown in (Fig. 14). It is clear that both the upper and lower epidermis composed of nearly compactly arranged rectangular cells with cuticularised outer walls. Stomata occur on both sides. The mesophyll consists of two layers of columnar palisade parenchyma occur both towards upper and lower epidermis (except midrib region and rounded ends of the margin) and spongy cells are located in between. The central portion of the mesophyll contains tannins. The cells (two layers of cells) beneath the upper and lower epidermis at midrib region and the cells at rounded ends of the margin are relatively large square-shaped and thin-walled also contain tannins.

At the midrib region, both upper and lower epidermis are convex. Vascular bundles of the midvein are accompanied from above and below by schlerenchyma tissue connected the phloem of each bundle to the epidermis. The xylems of the 

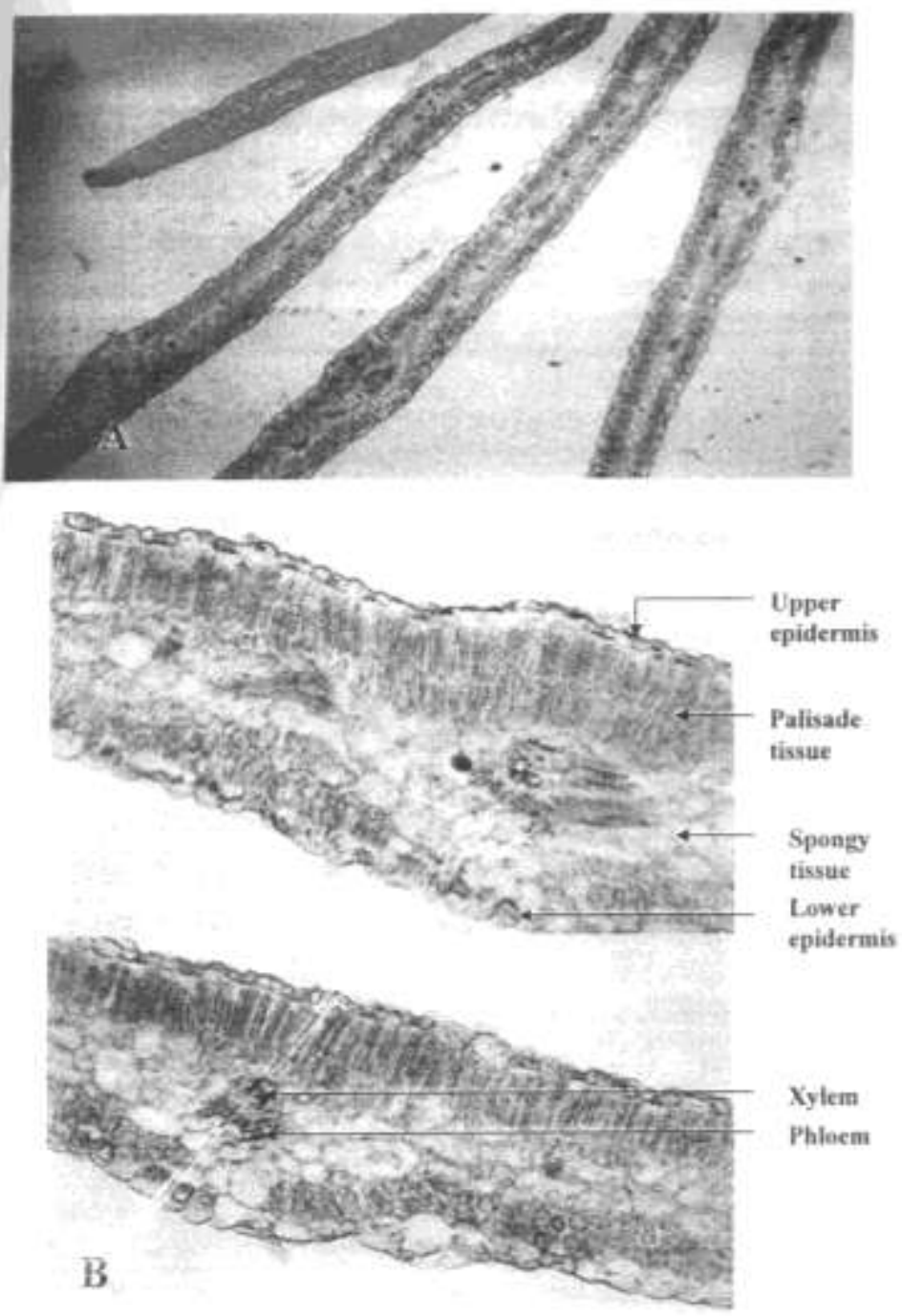

Xylem

Phleem

Sig. (13): Transverse sections through the leaflets of the compound leaf of Acacia salignu.

A. Whole sections. (X 52)

B. Magaified portios of A. $(X$ 144) 


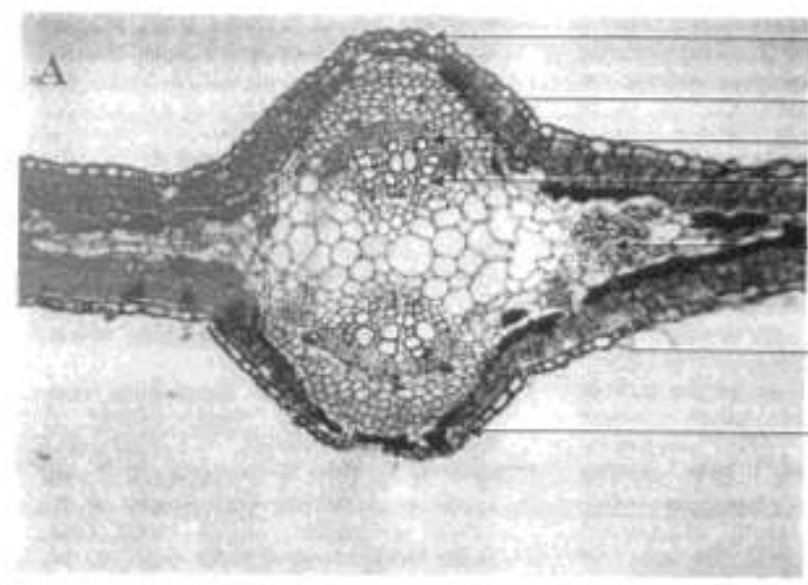

Upper epidermis Selerenchyma

Phloen

Xylem

Spong

tissue

Palisade

tissue

Lewer epidermis

B

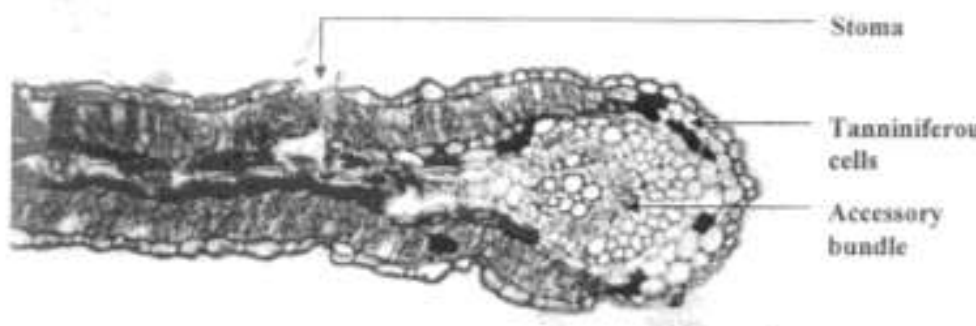

Fig. (14k Trasverne section through the yeung phyllodes of Acacia saljewa. (X:S)

A. Midrib rvgieas.

B. Margial portion. 

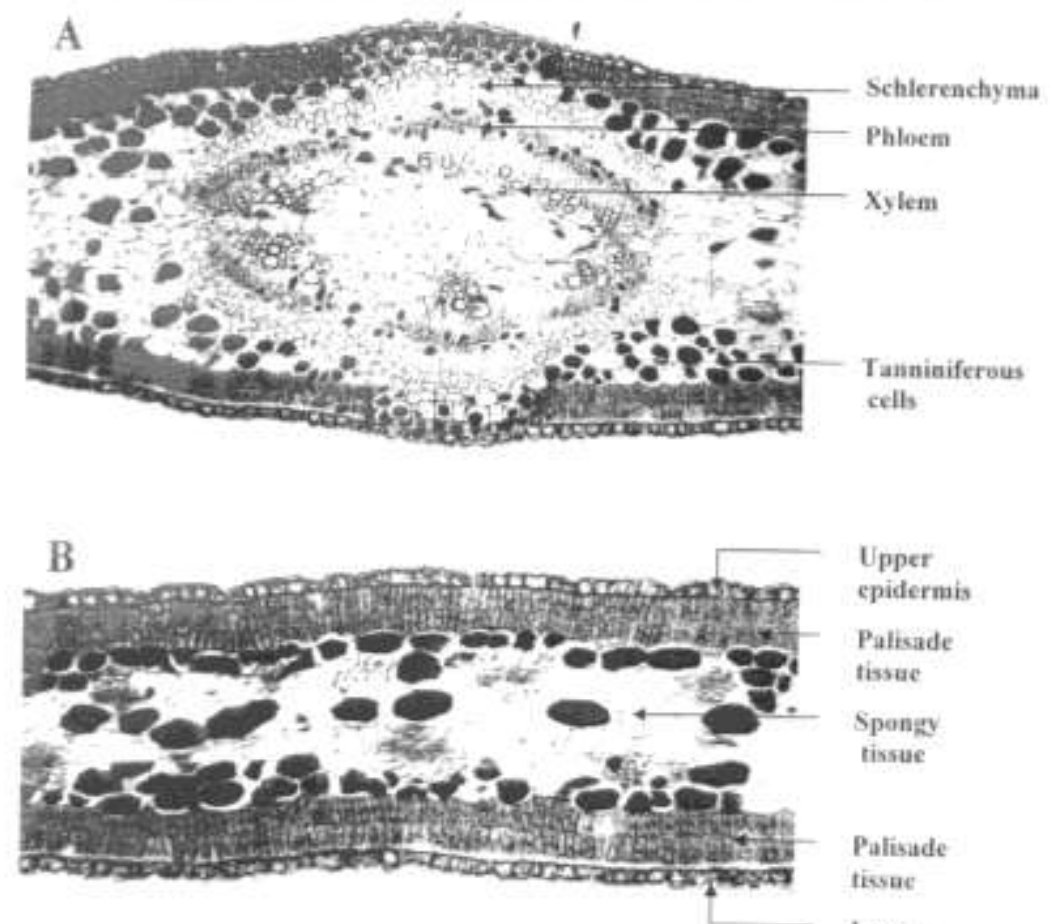

Upper epidermis Palisade tissue Spongy tixsue

Palisade tissac Lower epidermis

C

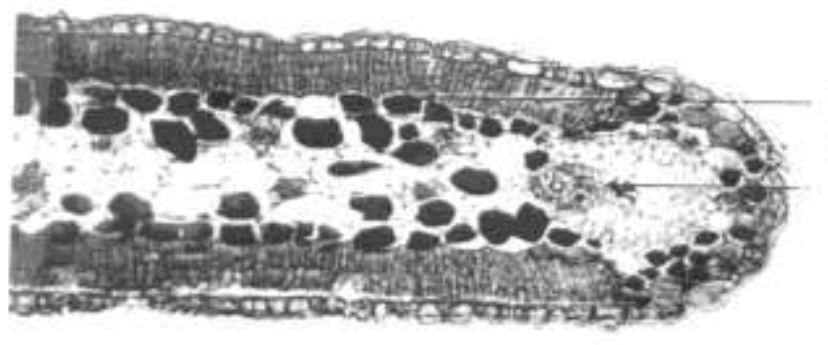

Tanainiferous cells Aceessory hundle

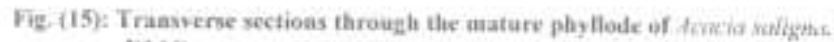

$\mathrm{X} 144)$

A. Midrib reston.

B. Blade.

C. Margiual portioa. 
opposed pairs of bundles being directed towards one another. There are also two accessory bundles, one of them lies at the right end and the other at the left end of the rounded margin.

\subsubsection{Structure of the mature phyllode}

The transverse section through the mature phyllode shown in Fig. (15) reveals that it has in general, the same structure of the young phyllode. The upper and lower epidermis are composed of compactly arranged rectangular cells. The cuticle is present on both epidermis as a thick layer but it is more towards the upper epidermis. Stomata present on both surfaces. The mesophyll is differentiated into palisade and spongy cells. The palisade tissue occurs just below the upper and lower epidermis (except midrib region and rounded ends of the margin) and consists of two layers of columnar parenchyma being characterized by an abundance of chloroplasts. The spongy tissue lies between the two palisade layers and consists of quite loosely arranged chlorenchymatous cells with conspicuous intercellular spaces. The cells contain comparatively lesser chloroplasts. The central region of the mesophyll contains tanniniferous materials. The cells underlying the upper and lower epidermis at midrib region and at rounded ends of the margin consist of three layers of square shaped cells filled with tannins.

At the midrib region, both upper and lower epidermis are somewhat convex. Vascular bundles of the midvein are arranged in a continuous ring. The xylems of the opposed pairs of bundles being directed towards one another. Vascular bundles of the midvein are accompanied from above and below by schlerenchyma tissue connected the phloem of each bundle to the epidermis. Tanniniferous materials also appear in phloem and xylem. There are also two accessory bundles lying at right and left ends of the margin.

Studies dealing with the anatomical structure of Acacia saligna phyllode are scarce, Metcalfe and Chalk (1979) stated that phyllodes are common in genus Acacia. The vascular bundles are arranged in a ring, compressed to correspond with the flattened shape of the phyllode. Central portion of the mesophyll often differentiated from the remainder by being relatively free from chlorophyll, the cells instead often containing brown tanniniferous materials.

\section{REFERENCES}

Anon. (1980). Firewood Crops. Shrub and tree species for energy production. National Academy of Sciences, Washington, DC, USA.
Anon. (1998). Egypt : National Strategy and Action Plan for Biodiversity Conservation, Ministry of State for Environmental Affairs, Egyptian Environmental Affairs Agency, Department of Nature Conservation, National Biodiversity Unit. $85 \mathrm{pp}$.

Anon. (2001). Egypt's Protected Areas, Ministry of State for Environmental Affairs. National Parks of Egypt.

Anon. (2008). Issues of Ministry of State for Environmental Affairs, Egyptian Environmental Affairs Agency.

Blakesley D., Allen A., Pellny T. K. and Roberts A. (2002). Natural and induced polyploidy in Acacia dealbata Link. and Acacia mangium Willd. Annals of Botany 90: 391-398.

Danin A. (1983). Desert Vegetation of Israel and Sinai. Jerusalem : Cana Publishing House: 148 pp.

Danin A. (1986). Flora and vegetation of Sinai. Proceedings of the Royal Society of Edinburgh, 89 B: 159-168.

El-Sahhar K. F., Amer W. M., Nassar D. M. and Qasem L. A. (2009). Plant wildlife in AlAhrash protectorate, Rafah, north Sinai, Egypt. Bull. Fac. Agric., Cairo Univ., 60: 6173.

Evert R. F. (2006). Esau's Plant Anatomy. $3^{\text {rd. }}$ Edit. John Wiley \& Sons, Inc.

Fahn A. (1959). Xylem structure and annual rhythm of development in trees and shrubs of the desert III. Eucalyptus camaldulensis and Acacia cyanophylla. Bull. Res. Counc. of Israel $70: 122-131$.

Fahn A., Waisel Y. and Benjamini L. (1968). Cambial activity in Acacia raddiana Savi. Annals of Botany 32 : 677-686.

Fox J. E. D. (1995). A review of the ecological characteristics of Acacia saligna (Labill.) $\mathrm{H}$. Wendl. Mulga Research Centre Journal 12: 39-56.

Gómez - Acevedo S. L., Magallón S. and RicoArce L. (2007). Floral development in three species of Acacia (Leguminosae, Mimosoideae). Australian Journal of Botany $55: 30-41$.

Gourlay I. D. (1995). Growth ring characteristics of some African Acacia species, Journal of Tropical Ecology 11 : 121-140.

Hanna P. J. (1984). Anatomical features of the seed coat of Acacia kempeana (Mueller) which relate to increased germination rate induced by heat treatment. New Phytol. 96 : 23-29. 
Iqubal M. and Ghouse A. K. M. (1987). Anatomy of the vascular cambium of Acacia nilotica (L.) var. telia Troup (Mimosaceae) in relation to age and season. Bot. J. Linn. Soc. 94:385397.

Krebs G. L., Howard D. M., May D. and van Houtert M. (2003). The value of Acacia saligna as a source of fodder for ruminants. Rural Industries Research and Development Corporation (RIRDC) Pub. No. 02/165. Project No. CUT-6A. Kingston, Australia.

Kutiel P. B., Cohen O. and Shoshany M. (2004). Invasion rate of the alien species Acacia saligna within coastal sand dune habitats in Israel. Israel Journal of Plant Sciences 52: 115-124.

Lewis G. P. (2005). Tribe Acacieae. In "Legumes of the world". Eds. G. P. Lewis, B. D. Schrire, B. Mackinder and M. Lock. p. 187-191. Royal Botanic Gardens, Kew, London, U. K.
Maslin B. R. and McDonald M. W. (2004). Acacia Search : Evaluation of Acacia as a woody crop option for southern Australia. Rural Industries Research and Development, Canberra, Australia.

Metcalfe C. R. and Chalk L. (1979). Anatomy of the Dicotyledons (vol. 1). The Clarendon Press, Oxford, U. K.

Mikhail G. (2002). Egypt's Biodiversity and the Quest for Conservation. Ministry of State for Environmental Affairs. Egyptian Environmental Affairs Agency. 40 pp.

Nassar M. A. and El-Sahhar K. F. (1998). Botanical Preparations and Microscopy (Microtechnique). Academic Bookshop, Dokki, Giza, Egypt. 219 pp. (In Arabic).

So M. L. (2004). The occurrence of extrafloral nectaries in Hong Kong plants. Bot. Bull. Acad. Sin. 45:237-245.

\footnotetext{
Acacia saligna (Labill.) Wendl. دراسات مورفولوجية وتثريحية على الأكاشيا ساليجنا النوع النباتى السائد في محمية الأحراش بلئل برفح- شمال سيناء- مصر

قاسم فؤاد السحار ـ داليا محمد عبد العزيز نصار _* وفاء محروس عامر ـ لما أسعد قاسم

قسم النبات الزراعى ـ كلية الزراعة ق قسم النبات ـ كلية العلوم

جامعة القاهرة - الجيزة - ملزعر

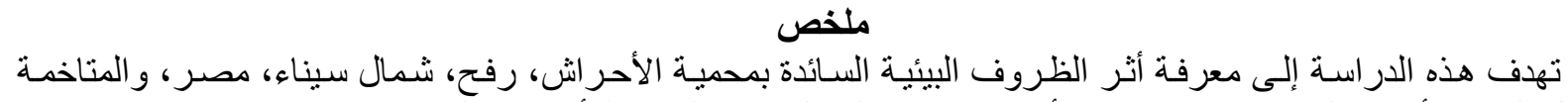



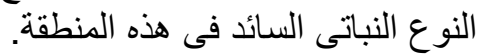

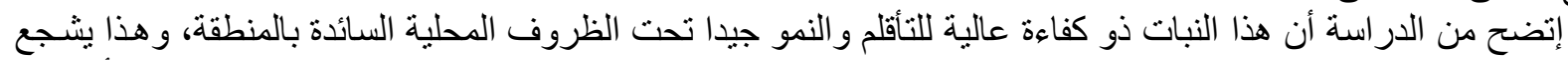

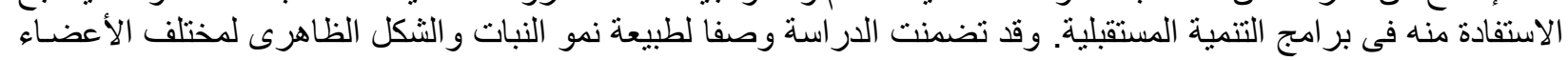

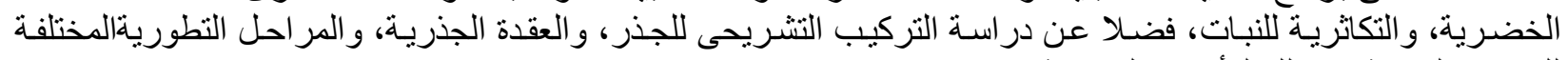

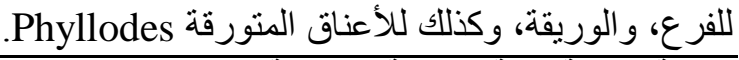

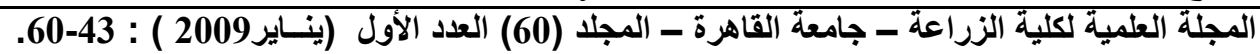

